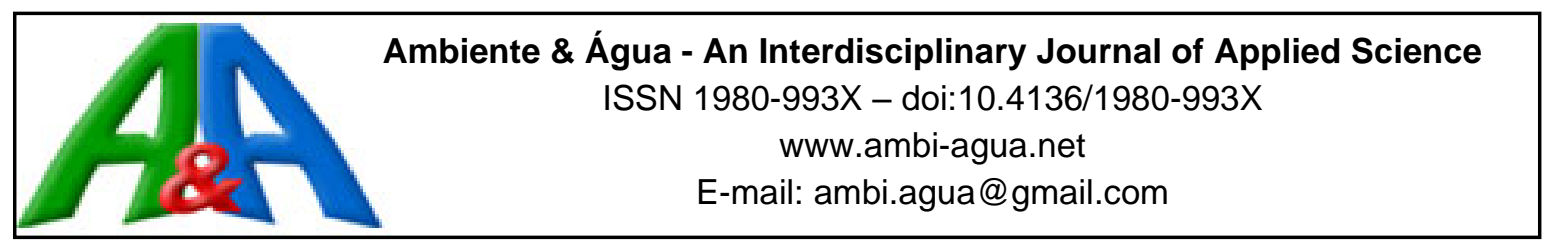

\title{
Soil bioengineering in northeastern Brazil: An Overview
}

\author{
ARTICLES doi:10.4136/ambi-agua.2650
}

Received: 21 Sep. 2020; Accepted: 24 May 2021

\section{Francisco Sandro Rodrigues Holanda ${ }^{1}$; Renisson Neponuceno de Araújo Filho ${ }^{\text {(D); }}$ Alceu Pedrotti $^{1}$; Bradford Paul Wilcox ${ }^{3}$; Regina Helena Marino ${ }^{1}$; Luiz Diego Vidal Santos ${ }^{4 *(D)}$}

\begin{abstract}
${ }^{1}$ Departamento de Engenharia Agronômica. Universidade Federal de Sergipe (UFS), Avenida Marechal Rondon, s/n, CEP: 49100-000, São Cristóvão, SE, Brazil. E-mail: fholanda@infonet.com.br, alceupedrotti@gmail.com, rehmarino@hotmail.com

${ }^{2}$ Departamento de Engenharia Florestal. Universidade Federal do Tocantins (UFT), Rua Badejos, s/n, CEP: 77404-970, Gurupi, TO, Brazil. E-mail: renisson@uft.edu.br

${ }^{3}$ Departament Ecology \& Conservation Biology. Texas A\&M University, Building 1537 - 534, 77843, John Kimbrough Blvd, College Station, Texas, United States. E-mail: bwilcox@tamu.edu ${ }^{4}$ Programa de Pós-graduação em Ciências da Propriedade Intelectual. Universidade Federal de Sergipe (UFS), Cidade Universitária Professor José Aloísio de Campos, Avenida Marechal Rondon, s/n, CEP: 49100-000, São Cristóvão, SE, Brazil.

*Corresponding author. E-mail: vidal.center@academico.ufs.br
\end{abstract}

\begin{abstract}
This article presents an overview of the application of soil bioengineering techniques, also modeled as natural engineering, in the state of Sergipe, northeastern Brazil, showing the importance of integrating living and inert elements to protect river banks from erosion. The employed techniques are different, ranging from the characterization of susceptibility to erosion to the use of biotechniques, considering knowledge in the areas of agronomic engineering, forestry engineering, civil engineering, biology, pedology, geology, geomorphology and geotechnics. It is an approach that uses techniques and methodologies in a multidisciplinary way, seeking to maximize synergies (for example, natural engineering techniques to combine inert materials in ways that help plants to develop increasingly efficient systems). This approach also considers maintenance-cost optimization in the conduction of the works, using different materials, differing from traditional engineering, which uses predominantly inert materials. The research work carried out in different locations sought the availability of local materials such as rocks, geotextiles made from fibers from the native flora or even available on the market, in addition to the use of native species to recovery of the banks or slopes, according to the ecological conditions of the northeastern Brazil. Size and technological and ecological reach were also considered, in addition to different biotechnical aesthetic objectives adapted to different situations.
\end{abstract}

Keywords: biotechniques, environmental degradation, erosion, natural engineering.

\section{Um panorama da Bioengenharia de solos no nordeste do Brasil}

\section{RESUMO}

Este artigo apresenta uma visão geral da aplicação das técnicas de bioengenharia de solos também conhecidas como engenharia natural no estado de Sergipe, nordeste do Brasil,

This is an Open Access article distributed under the terms of the Creative Commons Attribution License, which permits unrestricted use, distribution, and reproduction in any medium, provided the original work is properly cited. 
mostrando a importância da integração de elementos vivos e inertes para controlar a erosão nas margens dos rios. São abordados aspectos que vão desde a caracterização da susceptibilidade à erosão até o uso de biotécnicas, considerando conhecimentos das áreas da engenharia agronômica, engenharia florestal, engenharia civil, biologia, pedologia, geologia, geomorfologia e geotecnia. É uma abordagem que trabalha técnicas e metodologias de forma multidisciplinar buscando maximizar sinergias (por exemplo, técnicas de engenharia natural para combinar materiais inertes de maneira a ajudar as plantas a desenvolver sistemas cada vez mais eficientes). Essa abordagem também considera na condução dos trabalhos, a otimização de custos de manutenção, com uso de materiais diversos, diferente da engenharia tradicional que usa predominantemente materiais inertes. Os trabalhos de pesquisa conduzidos em diferentes localidades consideraram a disponibilidade de materiais locais como rochas, geotêxteis fabricados a partir de fibras da flora nativa ou mesmo disponíveis no mercado, além da utilização das espécies nativas para repovoamento das margens ou taludes, adequadas às condições ecológicas dos ambientes do Nordeste do Brasil. Também foi considerado o tamanho e alcance tecnológico e ecológico, além de objetivos estéticos apresentando diferentes biotécnicas adaptadas para diferentes situações.

Palavras-chave: bioténicas, degradação ambiental, engenharia natural, erosão.

\section{INTRODUCTION}

The formation of large reservoirs through the construction of hydroelectric plants, and the operation of these systems, have resulted in changes in the patterns and characteristics of river flows (Dai and Liu, 2013). These sudden changes to the water regime brought about by regulated flow, including alterations in the discharge behavior and in the transport of river sediments, created strong imbalances. An example is the São Francisco River, the third largest in Brazil, in the northeastern region; negative environmental effects can be seen across valleys, especially in the river's more vulnerable lower course, where the erosion of the riverbank has sped up.

The new hydro sedimentological regime that has been established has led to a new morphodynamic behavior that appears to be the primary cause of erosion of the riverbank (Pal et al., 2017; Rocha et al., 2018). In rivers with braided channels, such as the São Francisco River, it is noticeable that these channels subdivide and meet randomly, being separated by banks and sandbars. Because of their weak resistances, the margins are quickly attacked by erosion (Figure 1).
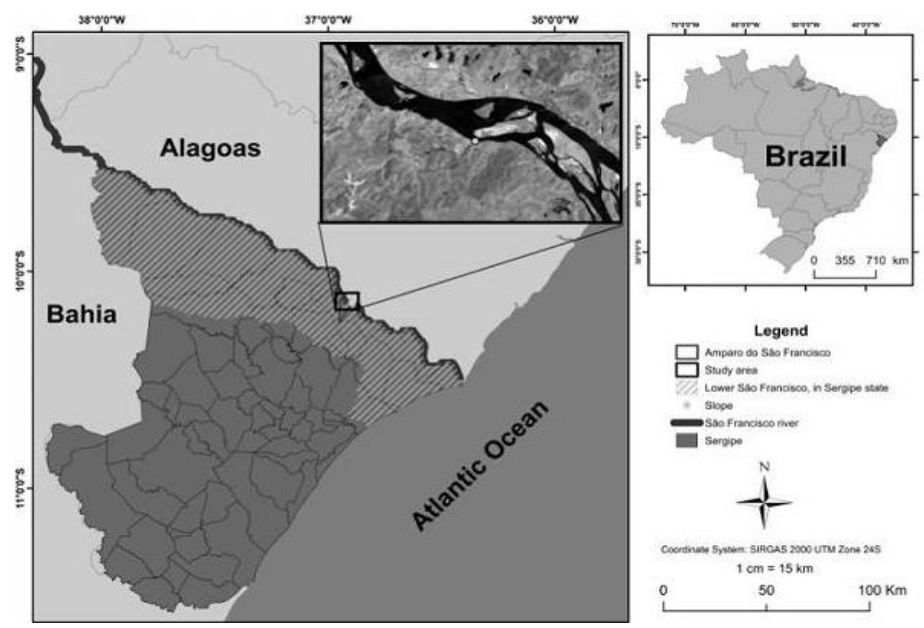

Figure 1. Location of the Lower São Francisco River in the state of Sergipe, with emphasis on the studied area. 
The triggering of erosion and sedimentation are evidence of the complex readjustments taking place in the channel morphology, as a new dynamic equilibrium is sought. The mechanisms of slope destabilization at the margin of the Lower São Francisco have been studied by Holanda et al. (2007) (Figure 2) through observation of the differences in behavior between the soil layers of slopes and erosion on the river bank. The authors stated that, over 30 years, in some stretches the margin retreats ranged from a maximum distance of $309.15 \mathrm{~m}$ to a minimum distance of $12.26 \mathrm{~m}$.
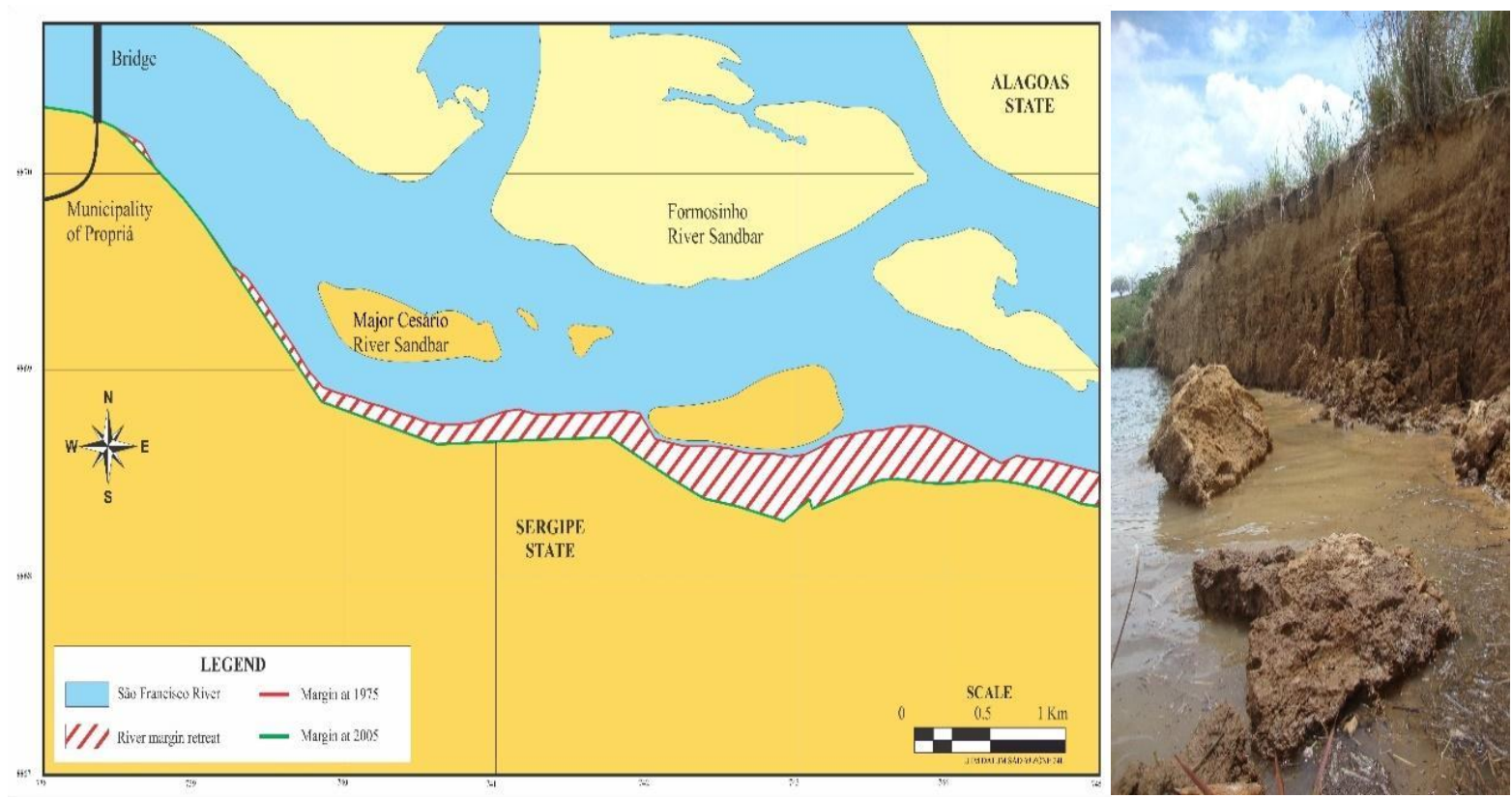

Figure 2. Margin retreat of the Lower São Francisco River from 1975 to 2005, resulting from river bank erosion.

Source: Holanda et al. (2007).

The extent of bank erosion may vary markedly from one point to another of the margin, because of varying morphological and sedimentological slope characteristics. In addition, the incidence angle of flow at the margin often varies from one location to another, depending on the direction in which the river channel is forming (Bordoloi et al., 2020; Fox and Felice, 2014; Langat et al., 2019; Liu et al., 2017; Rocha et al., 2013). Erosion occurs perpendicularly and large landslides are generated, causing a rapid retreat of the margin line; and when the current is parallel, landslides are predominantly small and cause only minor retreats (Rocha et al., 2018).

Wave action is a significant component in the bank erosion processes of the Lower São Francisco River, especially when the angle wave incidence is parallel to the shore. In this stretch of the river, a specific form of interaction takes place between waves and the river current, one that creates concavities in the bank curve wherein the retreat rates are the highest. The wave fronts arise from the east, the predominant wind direction (40\%), and are redirected to the south or southwest by the flow of the river (Figure 3). The wave action carries away large volumes of the eroded soil, a process that alters the river's geomorphological pattern, increases sediment deposition in the river bed, and leads to the formation of sandbars in certain zones (Holanda et al., 2012a).

A major cause of bank erosion of the Lower São Francisco River is the hourly ebb and flow between the aquifer and the river channel as water levels oscillate, governed by the volume of water released by the Xingó hydroelectric plant, which varies with the demand for energy (Holanda et al., 2009c). The daily variations in the water level produce ebbs and flows. When the water level rises, a hydraulic gradient develops in the direction of the river channel into the 
material of the margin. When the water level falls, a large groundwater flow is produced at the base of the slope, making the marginal slopes more susceptible to landslides. The movement of groundwater towards the river can generate seepage at points of upwelling, and the groundwater carries away fine soil particles (known as erosion or underground piping). Such particle removal undermines and destabilizes the base of the riverbank, accelerating its erosion (Bandeira et al., 2012).

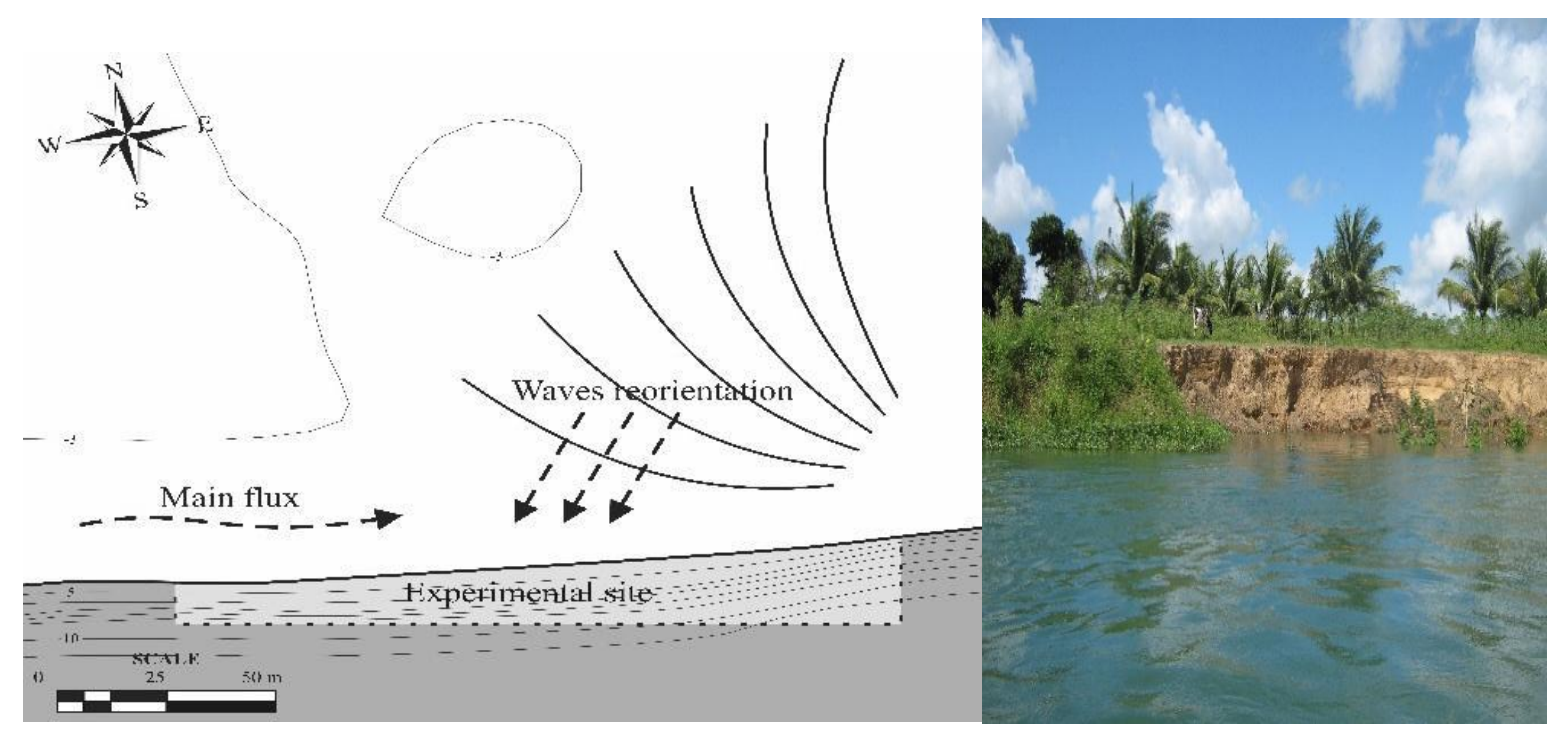

Figure 3. Topo/bathymetry showing the wind compass of prevailing winds and reorientation of the wave front, and the thalweg (dashed line) of a concave river bank.

Source: Rocha et al. (2013).

The soil loss, mostly related to erodibility, is partially explained by the soil texture. Erodibility is defined as the integrated effect of processes that regulate the rain at the time that finds the soil and its respective resistance, showing the degree in erosion susceptibility related to soil properties (Moura et al., 2017). Soils with little cohesion, such as those dominated by sand texture, are more susceptible to erosion by water. As the speed of the river flow increases, so does its transport capacity. Thus, when rivers overflow their banks, as is common at the beginning of the rainy season or during peak flows, the sediment concentrations rise (AraujoFilho et al., 2017).

Erosive effects are greater the closer the thalweg lies to the river bank, which is the zone of greatest turbulence (because flow velocities are higher and generate more energy that can produce landslides) such as in the sedimentary stretch of the São Francisco River margin (Holanda et al., 2021a; Li et al., 2017; Rocha et al., 2013).

\section{DEVELOPMENT OF RIVER BANK EROSION}

River bank erosion is affected by many factors, including the height, geometry, and structure of the bank; the mechanical properties of the materials composing the river margin; the hydrological characteristics of the flow near the margins and climatic conditions (Beck et al., 2018; Kotoky and Dutta, 2015; Thorne, 1981).

To characterize susceptibility to erosion, several soil attributes must be known such as the association between cohesion, the friction angle of solid particles, and the soil void ratio (the ratio between the volume of voids and the volume of solids in the soil (Caputo, 1988), and also the shear strength (Braida et al., 2007; Holanda et al., 2021b), as defined by Silva and Cabeda (2005), is the maximum shear stress that the soil can withstand without rupture. Shear strength is highly affected by moisture conditions (i.e. water content), especially if the soil contains clay 
materials (Bláhová et al., 2013), which is oriented by the shape and distribution of soil particles, soil structure, soil density, soil water content, type of clay mineral content, type and amount of cations, and forces of repulsion and attraction between particles (Braida et al., 2007; McCormack and Wilding, 1979; Thorne, 1981)

Knowing the physical attributes and the mechanical properties of a riverbank soil, such as: bulk density, particle-size distribution, cohesion and internal friction angle, and their intrinsic relationships, is important for a better understanding of the erosive process acting, thus enabling the generation information aimed at increasing its stability. During recent slope studies of the São Francisco riverbanks, it was found that the void ratio of samples varied with applied tension (Table 1): $\mathrm{kPa}$ values were near 100 when the volume of soil solids was approximately equal to the volume of voids. Proportionately, saturation showed the same behavior, that is, the lower the void ratio, the larger the voids filling with water. River banks composed of alluvial soils showed differences from sample to sample, demonstrating variability both vertically and horizontally. The greatest differences in void ratio were seen between Samples 1 and 3, with Sample 1 having the highest value (0.84); this soil, classified as soft and porous, also had the lowest particle density.

Table 1. Physical and mechanical properties of soil samples submitted to shear stress under tensions of 50, 100, 150, and $200 \mathrm{kPa}$.

\begin{tabular}{cccccc}
\hline Sample & Tension & Particle Density & Soil Void Ratio & Saturation Degree & Moisture \\
\hline & $\mathrm{kPa}$ & $\mathrm{g} \mathrm{cm}^{-3}$ & $\%$ & $\%$ & $\%$ \\
\hline \multirow{2}{*}{1} & 50 & $1.448 \mathrm{~b}$ & $0.82 \mathrm{~b}$ & $62.9 \mathrm{~b}$ & $19.51 \mathrm{~b}$ \\
& 100 & $1.428 \mathrm{~b}$ & $0.84 \mathrm{~b}$ & $58.9 \mathrm{~b}$ & $18.85 \mathrm{~b}$ \\
& 150 & $1.472 \mathrm{~b}$ & $0.78 \mathrm{~b}$ & $60.8 \mathrm{~b}$ & $18.2 \mathrm{~b}$ \\
& 200 & $1.490 \mathrm{~b}$ & $0.76 \mathrm{~b}$ & $56.9 \mathrm{~b}$ & $16.54 \mathrm{~b}$ \\
\hline \multirow{2}{*}{2} & 50 & $1.578 \mathrm{ab}$ & $0.67 \mathrm{ab}$ & $84.8 \mathrm{ab}$ & $21.63 \mathrm{ab}$ \\
& 100 & $1.567 \mathrm{ab}$ & $0.68 \mathrm{ab}$ & $83.2 \mathrm{ab}$ & $21.6 \mathrm{ab}$ \\
& 150 & $1.530 \mathrm{ab}$ & $0.72 \mathrm{ab}$ & $87.4 \mathrm{ab}$ & $24.06 \mathrm{ab}$ \\
& 200 & $1.502 \mathrm{ab}$ & $0.75 \mathrm{ab}$ & $79.3 \mathrm{ab}$ & $22.79 \mathrm{ab}$ \\
\hline & 50 & $1.737 \mathrm{a}$ & $0.53 \mathrm{a}$ & $97.9 \mathrm{a}$ & $19.64 \mathrm{a}$ \\
& 100 & $1.580 \mathrm{a}$ & $0.68 \mathrm{a}$ & $94.5 \mathrm{a}$ & $24.34 \mathrm{a}$ \\
& 150 & $1.564 \mathrm{a}$ & $0.70 \mathrm{a}$ & $85.5 \mathrm{a}$ & $22.60 \mathrm{a}$ \\
& 200 & $1.541 \mathrm{a}$ & $0.73 \mathrm{a}$ & $82.6 \mathrm{a}$ & $22.62 \mathrm{a}$ \\
\hline & $\mathrm{CV}(\%)$ & 3.83 & 8.25 & 6.23 & 7.16 \\
\hline
\end{tabular}

Means followed by the same lowercase letters do not differ significantly, according to the Tukey test $(\mathrm{P} \leq 0.05)$.

Source: Araujo Filho et al. (2017).

Variations in soil saturation in the samples reflect conditions found in the field, where humidity levels vary because of river current clashes at different frequencies, tensions, and load levels. These clashes lead to cyclical and random variations in mechanical and geotechnical soil behavior, which influence bank stability.

Along the river banks of the Lower São Francisco, specifically in the irrigated area called Cotinguiba-Pindoba, slope failures are associated with both the mechanical behavior of the soil and the established subsurface water flow. Thus, instrumentation was needed that would enable identification of the surface and subsurface mechanisms that operate in the existing or potential destabilization process, as well as mass movements observed on the slopes.

At the points where the main flow channel is near to the margin, the current speed increases substantially. This causes turbulence in the flow, which increases the current erosive power, 
mainly on the concave bank. The cohesive sediments, having low permeability, are more resistant to surface erosion which also reduces the negative effects of subsurface aqueous flows on the slope stability. However, when slopes are undercut and/or become saturated, mass movements of soil such as landslides and falling blocks occur frequently (Figure 4). The undercutting is caused by the action of waves at the overlap between the basal level and loamy sands, giving rise to failure in this layer of loamy sands; blocks that fall break down into smaller ones that slide to the bottom of the bank.
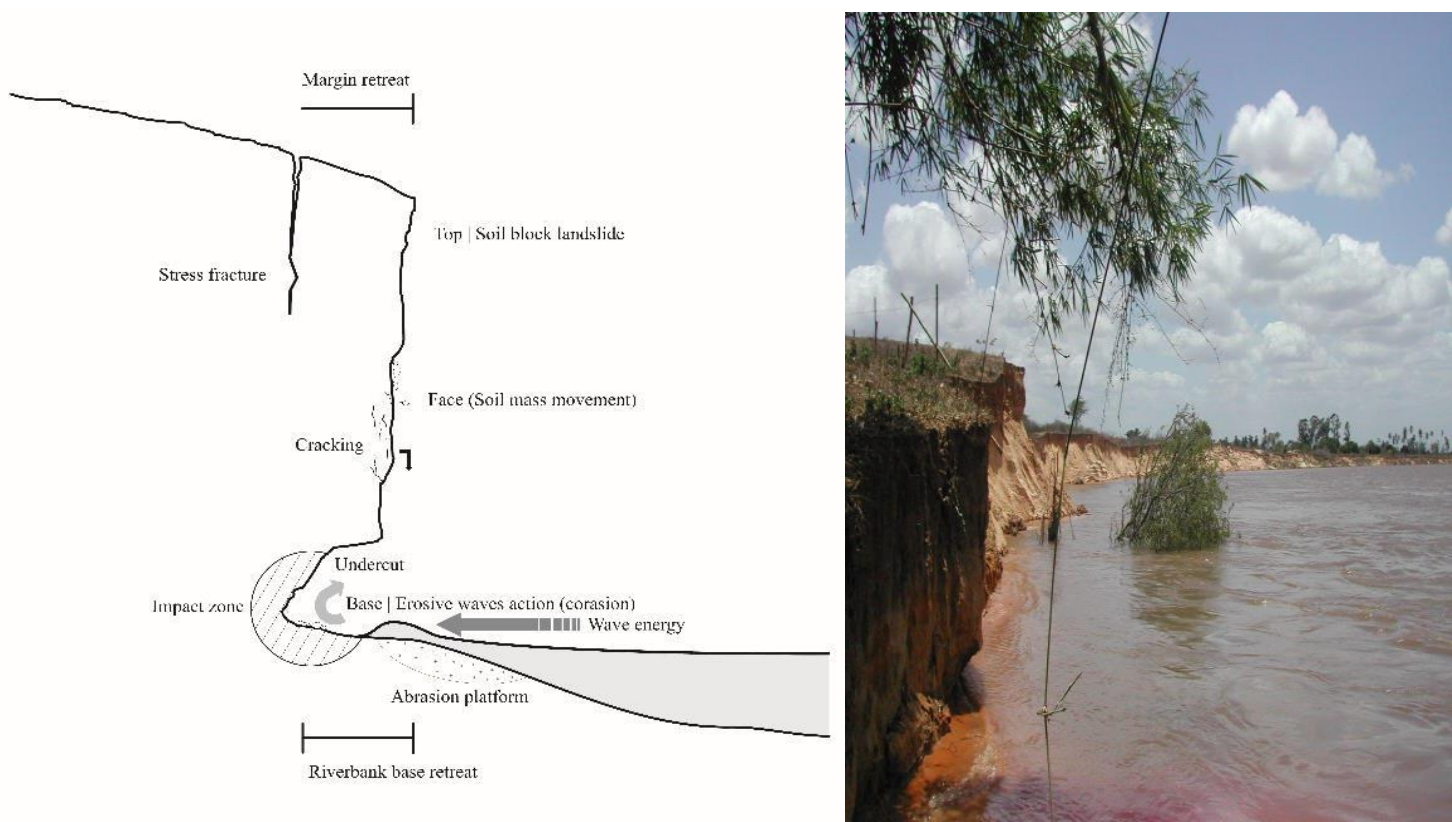

Figure 4. Undercutting and failure of river banks along the Lower São Francisco $\left(36^{\circ} 47^{\prime} 28.6^{\prime \prime} \mathrm{W}\right.$ and $\left.10^{\circ} 13^{\prime} 40.8^{\prime \prime} \mathrm{S}\right)$.

\section{MITIGATION OF RIVER BANK EROSION}

Measures to control the erosion of river or lakes banks, whether they are large, medium, or small, must consider not only geomorphological and geotechnical factors but also social factors, such as how these areas are occupied and used by the local people (Holanda et al., 2020; Machado et al., 2015). The adequate stabilization of river margins requires a combination of civil engineering technology and soil bioengineering.

The recovery of the banks of a water course that is undergoing active erosion is rather complex, because of the hydro sedimentological dynamic, especially along cleared river margins where there is little cohesive soil, which allows the erosion process to advance more rapidly.

To ensure the success and sustainability of remedial work, preliminary studies and analyses are indispensable. The erosion process must be quantified to assess its progress and to get the information needed to decide on the most appropriate mitigation measures and to plan policies for preventing or minimizing future problems.

As an example of remedial measures implemented for large rivers, since the 1980s riprap (massive stones) has been used to control erosion along the banks of the São Francisco River (Figure 5). Riverine population living along the river, concerned with flooding of their lands, have struggled to mitigate the degradation of the river banks using low-cost materials such as coconut (Coccus nucifera L.) straw, sandbags, and old rubber tires and inner tubes, with or without the assistance of public agencies in controlling the erosion. Although intended as an immediate solution to a genuine problem, it is important to note that such solutions carry their own environmental risks. 


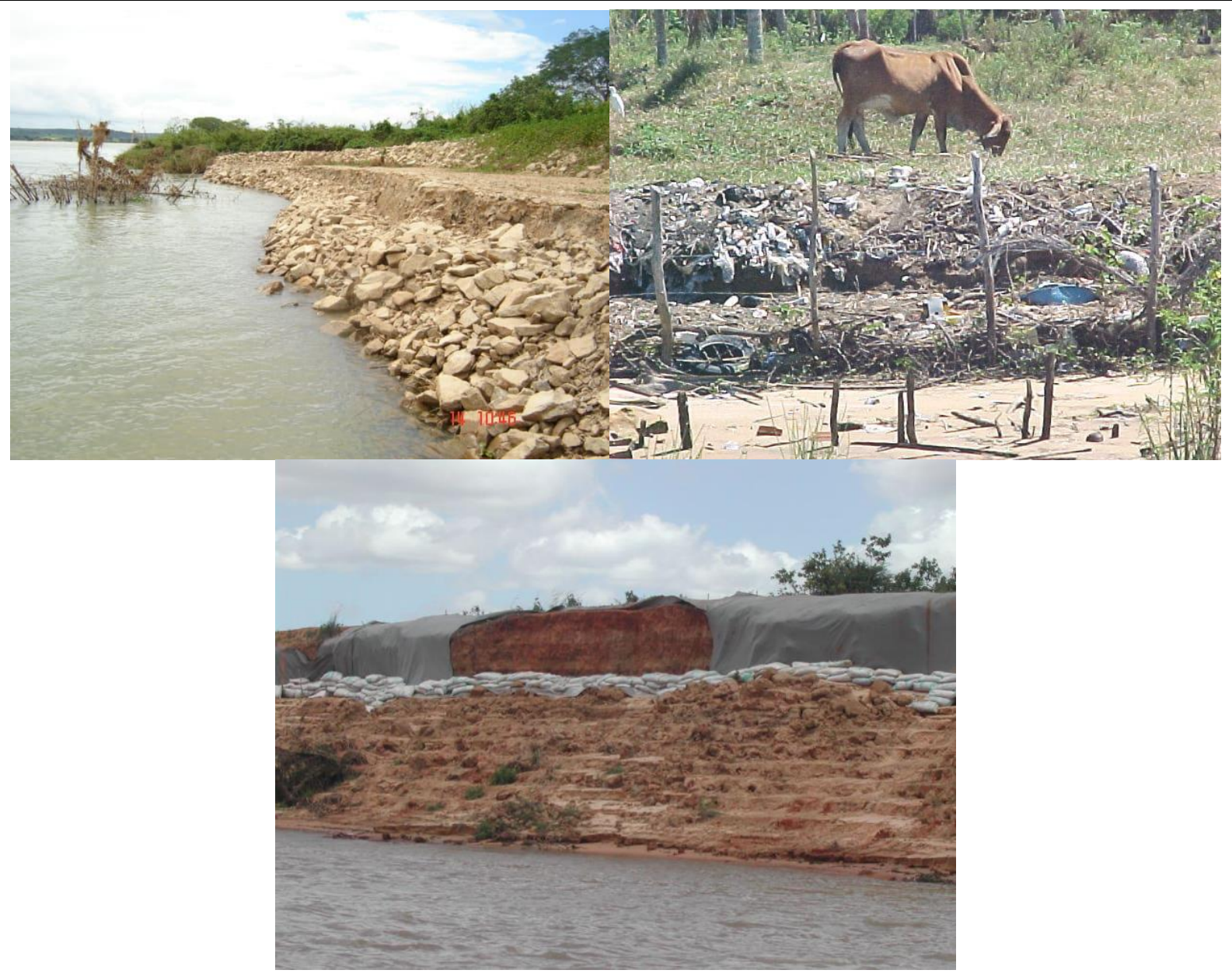

Figure 5. Riprap and other erosion-control methods used by the riverine population.

To overcome the problem of low cohesion of alluvial soils, riverbanks, normally entisols, rock material with an average diameter of $70 \mathrm{~cm}$ has been used on the local banks. This material not only retains the soil particles that were dragged by the underground erosion but also absorbs the impact of the waves on the face of the bank, avoiding the undercutting (Hiller et al., 2018; Holanda, et al., 2009b). The installation of riprap involves operations to smooth the river bank, followed by coating with rocky materials having a particle size scaled to absorb the impact of waves. The stability of loose (dumped) rock riprap against erosive forces due to flowing water was also studied by Jafarnejad et al. (2019), who agree that riprap is typically employed in locations where portions of the slope have been cut away and is considered an emergency measure to contain the river-bank erosion. This technique, however, even if implemented by engineering specialists, may not be a lasting solution, since the structure could eventually collapse as the erosion proceeds in the bank-toe.

Although efficient in many cases, the installation of hard structures like riprap and gabions has drawbacks: artificial margins thus created directly affect in the river ichthyofauna that use the slope area for food, shelter, and reproduction (Petts, 1987). Moreover, it is an expensive engineering technique and is usually implemented through public policies to revitalize river banks under a strong erosion threat. For these reasons, some soil bioengineering techniques whereby biologically active elements are integrated with inert elements such as rocks, concrete, wood, metal alloys, and natural and synthetic polymers (Birnbaum et al., 2018; Chilima et al., 2013; Chong and Chu, 2007; Morton et al., 2014; Petrone and Preti, 2010; Schiechtl and Stern, 1996) is the solution of choice. These biotechnical methods facilitate the development of riparian vegetation (Stokes et al., 2009), and decrease the rate of erosion and the subsequent 
corrasion (Holanda et al., 2008). Corrasion is commonly defined as mechanical abrasion by the turbulence of water loaded with solid particles, which undermines the base of the slope.

The conservation and stabilization of river banks is necessary for the restoration of riparian vegetation, to keep the erosion/sedimentation processes from accelerating. However, the best results are obtained by addressing slope erosion not simply mechanically but also from the ecological point of view (Durlo, 2005; Janssen et al., 2019). Soil bioengineering offers the possibility of using an abundant raw material to test solutions that are both economically justifiable and technically feasible (proven through experimental testing).

The development of an appropriate recovery model is based on information concerning its soils, hydrology, fluvial geomorphology, geo-technology, remnants of native vegetation, land use, history of human occupation, and empirical knowledge of the local area (Cavaille et al., 2013; Sweeney and Czapka, 2004). In addition, the natural processes of ecological succession must be considered (Testoni and Backes, 2009). Thus, a number of surveys were carried out to investigate the floristics, the local hydrology, and the history of erosive processes along the banks of the São Francisco River and the Paramopama Creek, both located in the state of Sergipe, Brazil, preliminary to the deployment of soil bioengineering techniques (Holanda et al., 2012c).

Along the Lower São Francisco River, Moura et al. (2017) performed an extensive floristic survey of riparian vegetation, identifying families and species as well as their growth habits (Table 2). Members of the local population were interviewed, to collect information on endemic species and species no longer found locally. Most of the vegetation along these rivers are remnants of the Atlantic rain forest, which used to cover 100 million hectares along the Brazilian Atlantic coast but is now reduced to isolated patches. In the state of Sergipe, these patches consist mostly of secondary forest. Records on local biodiversity are valuable for planning the recovery of riparian vegetation and have guided the selection of species for use in bioengineering (Landim et al., 2015; Ribeiro et al., 2009).

The effectiveness and durability of a soil bioengineering installation are directly related to the selected plant species; using not adopted species in these structures can lead to instability. In addition to emphasizing choice of native species, researchers point out the importance of identifying the most suitable methods of propagation for ensuring rapid growth and the development of deep root systems among those listed in the floristic survey. Root systems that extend beyond the surface of slope failure will improve the soil cohesion, thereby increasing the structure shear strength and thus strengthening the erosion control.

Concerning vegetative propagation, taking live cuttings from a matrix plant to grow new plants is one of the most widespread methods of propagation for forest species and for seedlings or cuttings of species (Holanda et al., 2012a) like Vetiver grass (Chrysopogon zizanioides (L.) Roberty) and Paspalum grass (Paspalum millegrana Schrad) Schinus terebinthifolius Raddi, Spondias lutea L., Inga marginata Wild, Tapirira guianensis Aubl, Lonchoncarpus sericeus (Poir.) DC, Mimosa caesalpiniaefolia Benth, Genipa americana L., Mimosa pigra L., Solanum paniculatum L., Sesbania virgata (Cav.) Pers. The biotechnical potential of Vetiver grass and Paspalum grass species lies in the resilience of its roots against the forces of traction and cutting, its resistance to strong mechanical stress, and its ability to create a structured soil by increasing the capillarity and permeability (Islam and Shahin, 2013; Mickovski and van Beek, 2009). According to Machado et al. (2018) the mean Root Tensile Strength (TR) of 83 MPA was obtained during testing of the Vetiver grass. However, the variability in TR may occur due to root age, growth rate, and growth orientation by changes in the soil moisture content, and soil texture, as was also stated by De Baets et al. (2008). To understand how the roots contribute to soil shear strength, one must examine the soil-root interactions. According to Silva and Cabeda (2005), roots can be viewed as flexible and elastic elements of relatively high resistance which, when inserted into the soil reinforce its resistance to possible slope landslides. 
Table 2. Species of riparian vegetation along the Lower São Francisco River banks in Sergipe State, northeastern Brazil.

\begin{tabular}{|c|c|c|c|c|c|}
\hline Family & Species & Growth Habit & Family & Species & Growth Habit \\
\hline Combretaceae & Terminalia catalpa $L$. & Tree & Rubiaceae & Anisomeris sp & Shrub \\
\hline Araceae & Montrichardia linifera Schott & Aquatic & Moraceae & Ficus eximia & Tree \\
\hline Annonaceae & Annona cacans & Tree & Mimosaceae & Inga edulis & Tree \\
\hline Graminae & Oryza sativa L. & Herbaceous & Rubiaceae & Genipa americana $L$. & Tree \\
\hline Pontederiaceae & Eichornia crassipes & Aquatic & Rhamnaceae & Zizyphus joazeiro Mart. & Tree \\
\hline Fabacea & Dalbergia ecastophyllum (I.) Taub. & Shrub & Ciperaceae & Eleocharis elegans & Aquatic \\
\hline Anacardiaceae & Spodias dulcis & Tree & Chrysobalanaceae & Couepia impressa & Tree \\
\hline Anacardiaceae & Anacardium ocidentale $L$. & Tree & Anacardiaceae & Mangifera indica & Tree \\
\hline Mimosaceae & Mimosa sp & Shrub & Passifloraceae & Passiflora sp & Liana \\
\hline Mirtaceae & Eugenia sp & Tree & Flacourtiaceae & Casearia sylvestris & Shrub \\
\hline Caesalpinoidea & Cassia fistula L. & Tree & Convolvulaceae & Ipomoaea fistulosa Mart & Herbaceous \\
\hline Poaceae & Bambusa vulgaris & Aquatic & Rosaceae & Licania humilis & Tree \\
\hline Caesalpinoidea & Caesalpinea pyramidalis Tull & Tree & Piperaceae & Piper arborium Aubl. & Shrub \\
\hline Meliaceae & Cedrela fissilis & Tree & Moraceae & Cecropia pachystachya & Tree \\
\hline Arecaceae & Cocos nucifera & Tree & Rubiaceae & Guettarda angelica & Shrub \\
\hline Bignoniaceae & Tabebuia caraiba Mart. & Tree & Myrtaceae & Psidium $s p$ & Shrub \\
\hline
\end{tabular}

Source: Holanda et al. (2005)

\section{SOIL BIOENGINEERING IN NORTHEASTERN BRAZIL}

Soil bioengineering in Sergipe was introduced in 2004, as a tool for decreasing the rate of erosion through corrasion. Because these erosive processes are quite common on the Lower São Francisco riverbanks, monitoring studies to better understand them had been carried out earlier, between 1998 and 2004. At that time, the use of riprap for the erosion control was widespread and was claimed to be the only tested solution in those hydro environmental conditions. The erosion reduced from the top of the slope is a direct result of the physical protection provided by the soil bioengineering techniques, a combination of traditional engineer techniques and live materials, done on the lower third of the slope, which reduces the amount of soil eroded into the river channel.

In order to mitigate the problems of slopes and river-bank erosion, soil bioengineering techniques have been employed all over the world. Among those widespread techniques already tested or adapted, successfully or not, in the Lower São Francisco and in other sites of the region during the period from 2004 to 2016, it is important to mention vegetated riprap, live cribwall, live fascines, brush layer, live stakes, vetiver grass contour line and others. 
The pioneering experimental studies with soil bioengineering were run on vertical slopes, each about $120 \mathrm{~m}$ long and $10 \mathrm{~m}$ wide, i.e., about $1,200 \mathrm{~m}^{2}\left(10^{\circ} 13^{\prime} 44.1^{\prime \prime} \mathrm{S}, 36^{\circ} 46^{\prime} 11.8^{\prime \prime} \mathrm{W}\right.$; and $\left.10^{\circ} 13^{\prime} 44.4^{\prime \prime} \mathrm{S}, 36^{\circ} 46^{\prime} 09.3^{\prime \prime} \mathrm{W}\right)$. Both slopes were characterized by very low cohesion, low shear strength, low friction angle $\left(17^{\circ}-25^{\circ}\right)$, and a Factor of Safety (FS) less than 1.0. Classified as unstable, these slopes were very susceptible to collapse by shearing.

These techniques use a mixture of inert materials, such as rocks, wood, natural fiber (geotextile) or synthetic photodegradable geotextile, with biological materials, such as shrubs or poaceae seedlings, as well as plant cuttings, seeds etc. In the design of structures for protecting the river banks from erosion, it is important to combine living and inert elements (Holanda et al., 2017; Machado et al., 2018). Geotextiles have been demonstrated to help stabilize slopes and to efficiently control bank erosion (Araújo-Filho et al., 2013; Holanda et al., 2009a; Ribeiro et al., 2011).

The soil bioengineering materials primarily used were geotextiles of $100 \%$ coconut fiber with photodegradable polypropylene (Figure 6). These were used as an erosion blanket protection on the alluvial soil of one of the slopes. The slope that was not treated with soil bioengineering techniques continued to erode severely. As shown in Figure 7, its transverse profile was significantly altered, mainly from the action of shock waves at the base of the slope, which led to the verticalization of the margin. This change in profile took place in less than a year, between September 2004 and March 2005 (Holanda et al., 2008), and in turn gave rise to frequent shear-induced mass movements of soil, with large blocks falling from the bank toe. In the treatment with soil bioengineering, the importance of living and inert elements in the physical protection of the slope against the effects of marginal erosion is perceptible. A combination of coconut (Coccus nucifera $\mathrm{L}$ ) geotextile with coir roll with biodegradable mesh and native species seeds cocktail was tested. The geotextile contributed to the stabilization of the slope and showed efficiency in the control of the erosion of the margins in the evaluated period.

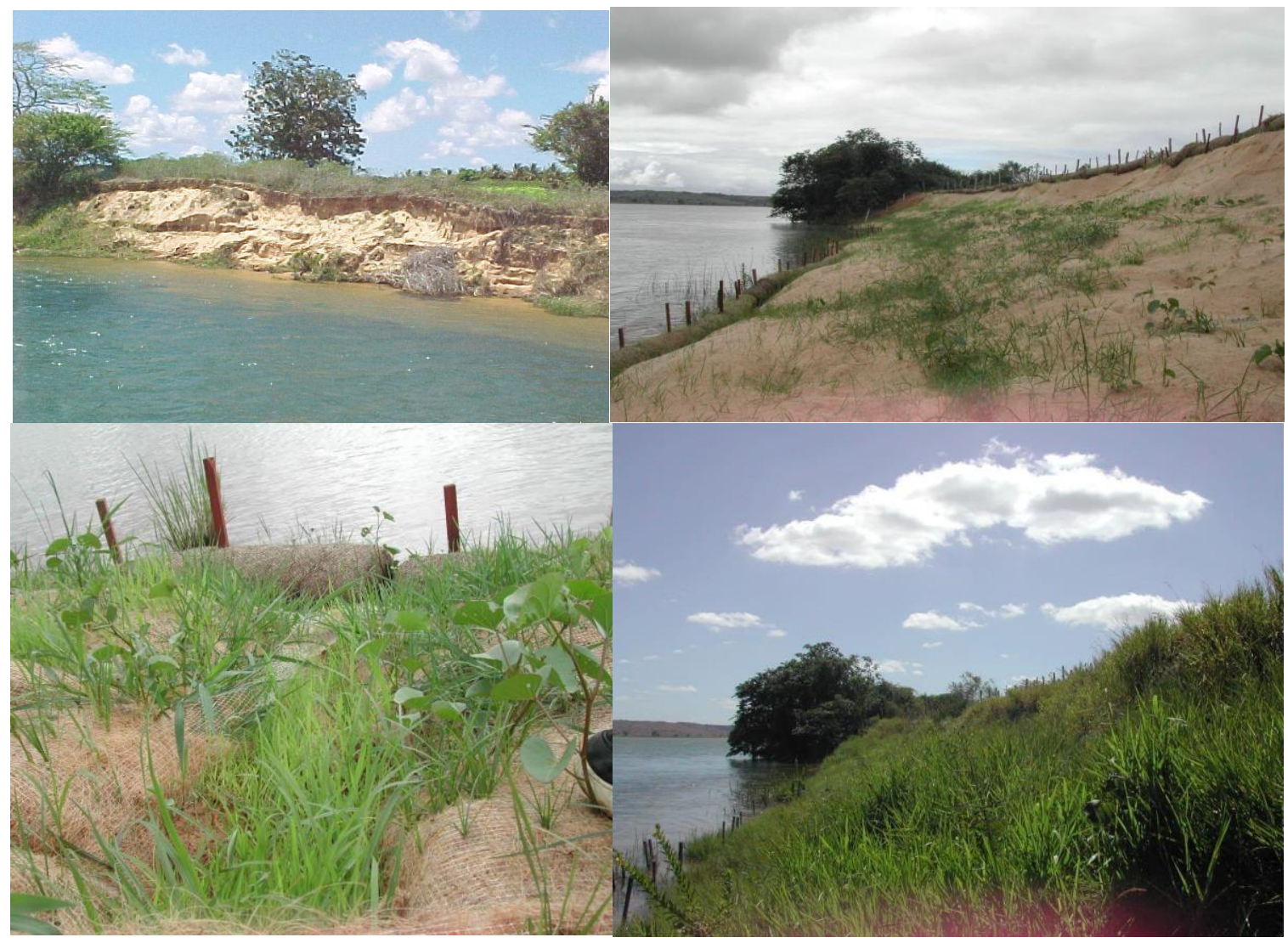

Figure 6. The use of soil bioengineering techniques to control erosion (Holanda et al., 2005). 

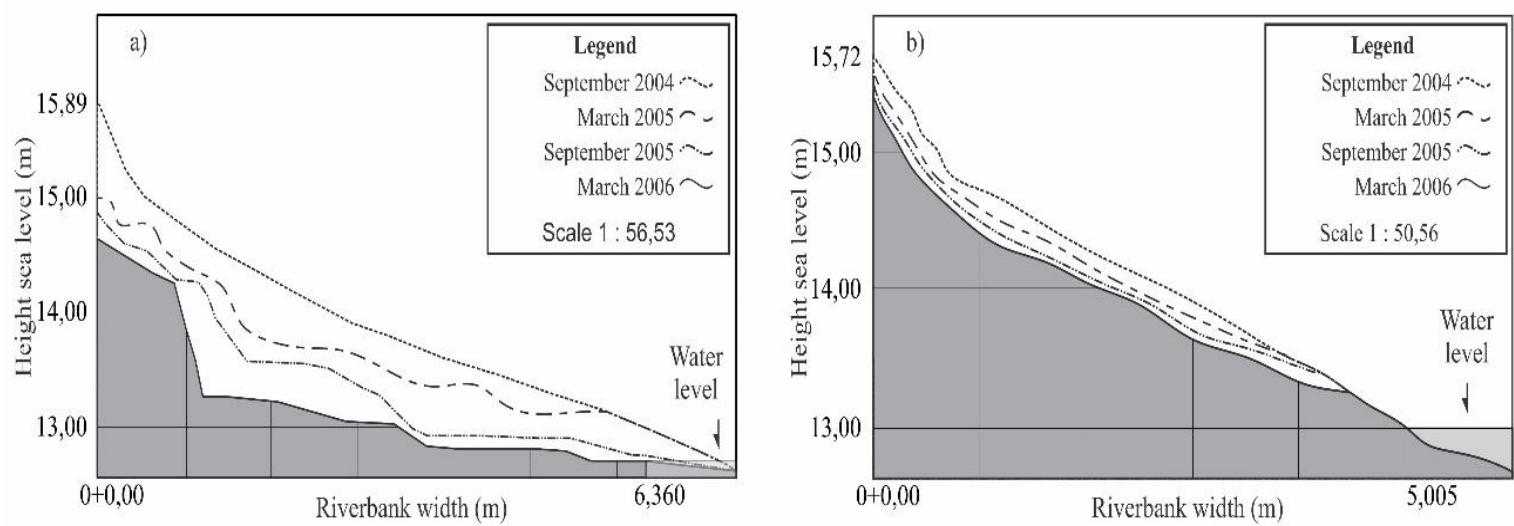

Figure 7. Comparison of river bank profiles: left panel untreated river bank; right panel riverbank treated with soil bioengineering techniques.

Source: Holanda et al. (2008).

A variety of studies have been done to investigate the usefulness of soil bioengineering techniques. All of them have used a combination of geotextiles and other devices designed to protect the slope toe, such as the gabion, a rectangular structure having a hexagonal mesh exterior of reinforced, galvanized wire. These structures range in width from $0.17 \mathrm{~m}$ to $0.30 \mathrm{~m}$ and are filled with non-friable stone. Plastic materials and natural or synthetic fibers are applied to the soil surface to supplement the protective effect of the vegetation. These materials reinforce the soil laterally and form a layer that acts as a surface blanket. Soil bioengineering protection of this kind was used for the bank restoration of both São Francisco and Paramopama Rivers (Ribeiro et al., 2011) (Figure 8).

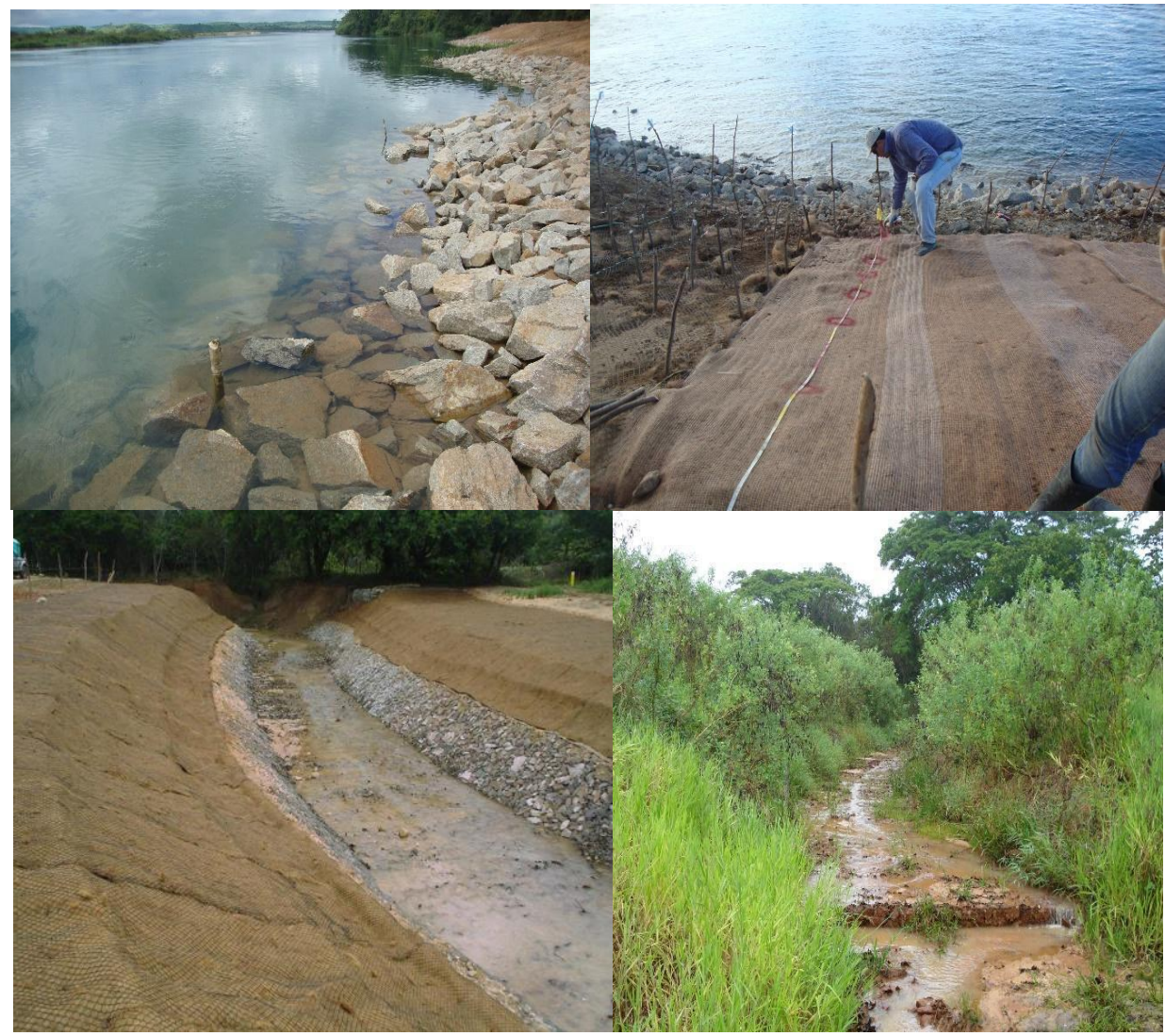

Figure 8. Use of geotextiles, with riprap and gabion as toe protection, on the banks of the São Francisco and Paramopama Rivers. 
Particularly in places where the geotextiles were still in good condition, we observed that stabilization of the margin soils had allowed for the establishment of arborous species propagated by seed dispersal as well as for the proliferation of native herbaceous species.

The decision to use geotextiles along both the lower São Francisco River and the Paramopama Creek was motivated by a recognition of the advantages offered by this biotechnical component, such as immediate protection against soil erosion, programmable degradation, and facilitation of revegetation.

The use of social technologies that enable possible innovation using local knowledge has been conducted to make geotextiles from the use of natural fibers routinely used for handicraft making in the Lower São Francisco of Sergipe state. The production of these geotextiles, using abundant natural resources at the collection sites, leads to the possibility of an additional source of income, as well as the contribution to erosion control, since the geotextiles offer support against soil mass transport and conditions favorable for the development of vegetative cover. We have been working on the manufacture of an efficient braid for erosion control in riverbanks or slopes, through its manufacture using fiber of the species Typha latifolia, Linn, Juncus spp Vahl. and Syagrus coronata (Mart.) Becc (Figure 9). This work has tried to get the real efficiency of the geotextiles made from the natural fibers in erosion control as part of the soil bioengineering techniques. At the same time, it is unknown whether the use of fibers produced from species found in the vicinity of riparian communities is sustainable, or whether the fibers used in the production of handicrafts in the studied communities for the production of geotextiles is suitable.

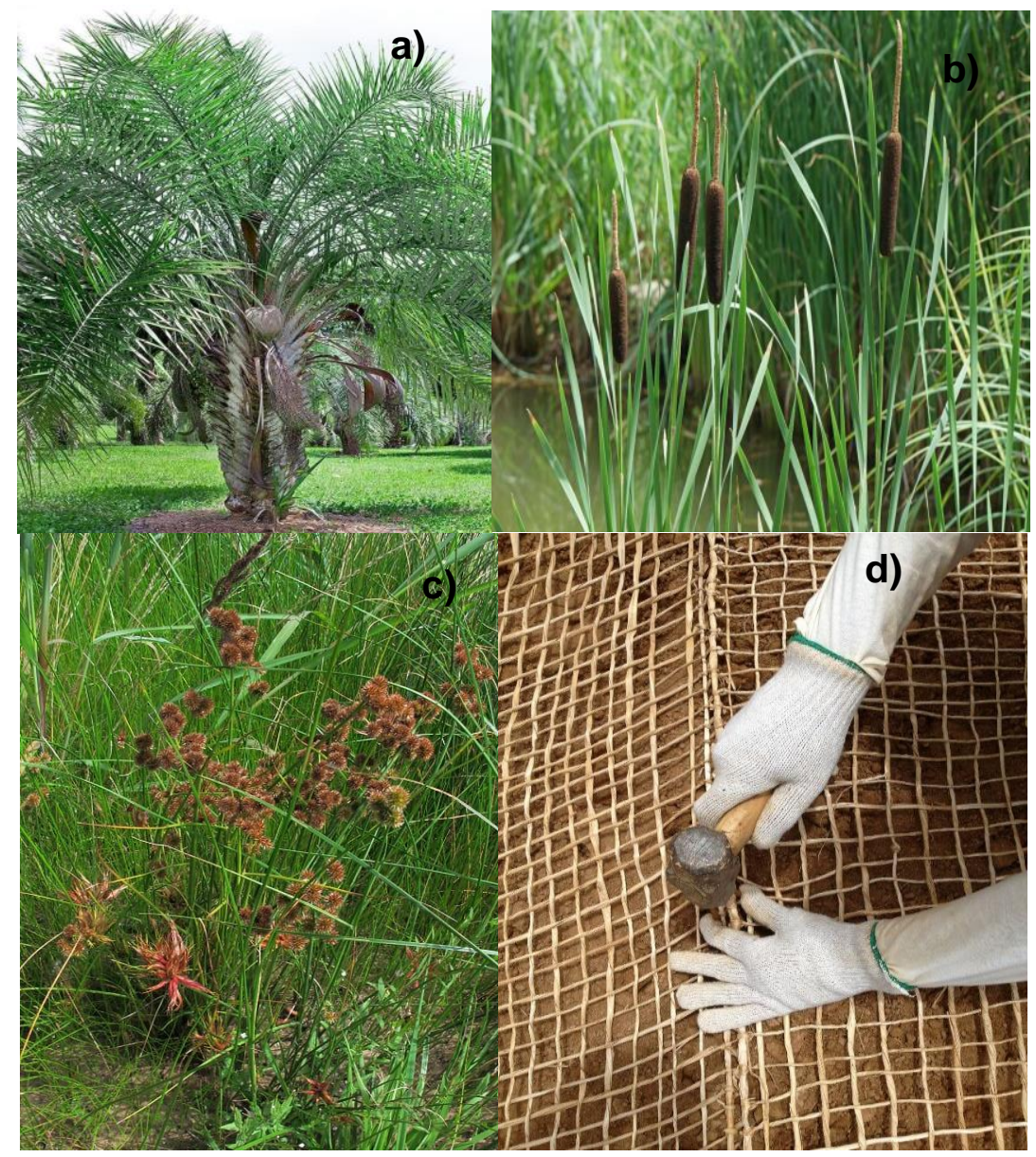

Figure 9. a) Plant of Syagrus coronata (Mart.) Becc., b) Plant of Typha latifolia, Linn., c) Plant of Juncus spp Vahl. (d) Use of Typha latifolia geotextile on the riverbank erosion control. 
Vegetated Riprap is one of the most widespread soil bioengineering techniques, characterized by the use of rocks to protect the base of unstable slopes. It is commonly associated with other techniques that use live stakes or geotextiles in the middle and upper slope (Figure 10). This comprises one of the soil bioengineering techniques used at the slope toe of the São Francisco riverbanks in 2011, with rock materials with different diameters, and vegetated with species of local flora, as listed in Table 2, and also populated with other species resulting from seed dispersal by fauna and the wind. Live fascines and brush layer were used with vegetated riprap, composed of species previously tested in assays, such as Schinus terebinthifolius Raddi, Erythrina velutina, Caesalpinia leiostachya e Enterolobium contorsiliquum, Spondias lutea L., Inga marginata Wild, Tapirira guianensis Aubl, Lonchoncarpus sericeus (Poir.), and Mimosa caesalpiniaefolia Benth L with very satisfactory results, especially S. terebinthifolius., M. caesalpiniaefolia, and Mimosa pigra (Holanda et al., 2010; 2012a).

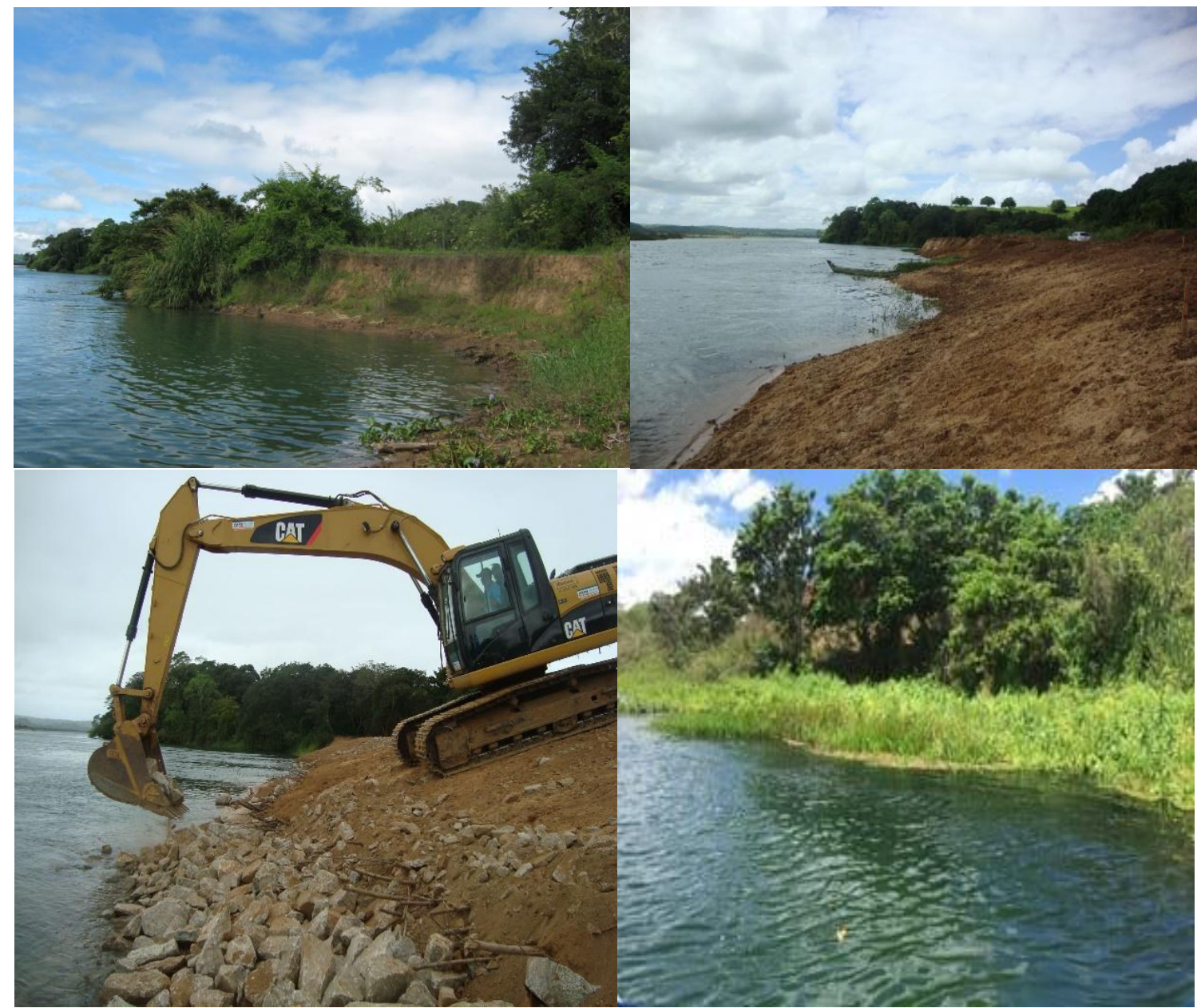

Figure 10. Lower São Francisco Riverbank recovery, Northeastern Brazil, through soil bioengineering technique called Vegetated riprap, from 2010 to 2018.

Live Cribwall is the most recent implanted technique, implanted in September 2013, which used inert materials, such as rocks as riprap (at the slope toe), wooden logs and clamps, together with biological materials also associated with brush layer for slope stabilization (Figure 11). This creates a favorable environment at the slope toe exposed to the ebb and flow of water, with the presence of aquatic macrophytes that cover and protect the slope, as time passes. The Vetiver grass Contour Line consists of seedlings of Vetiver grass planted in contour lines, mostly used in road slopes. 


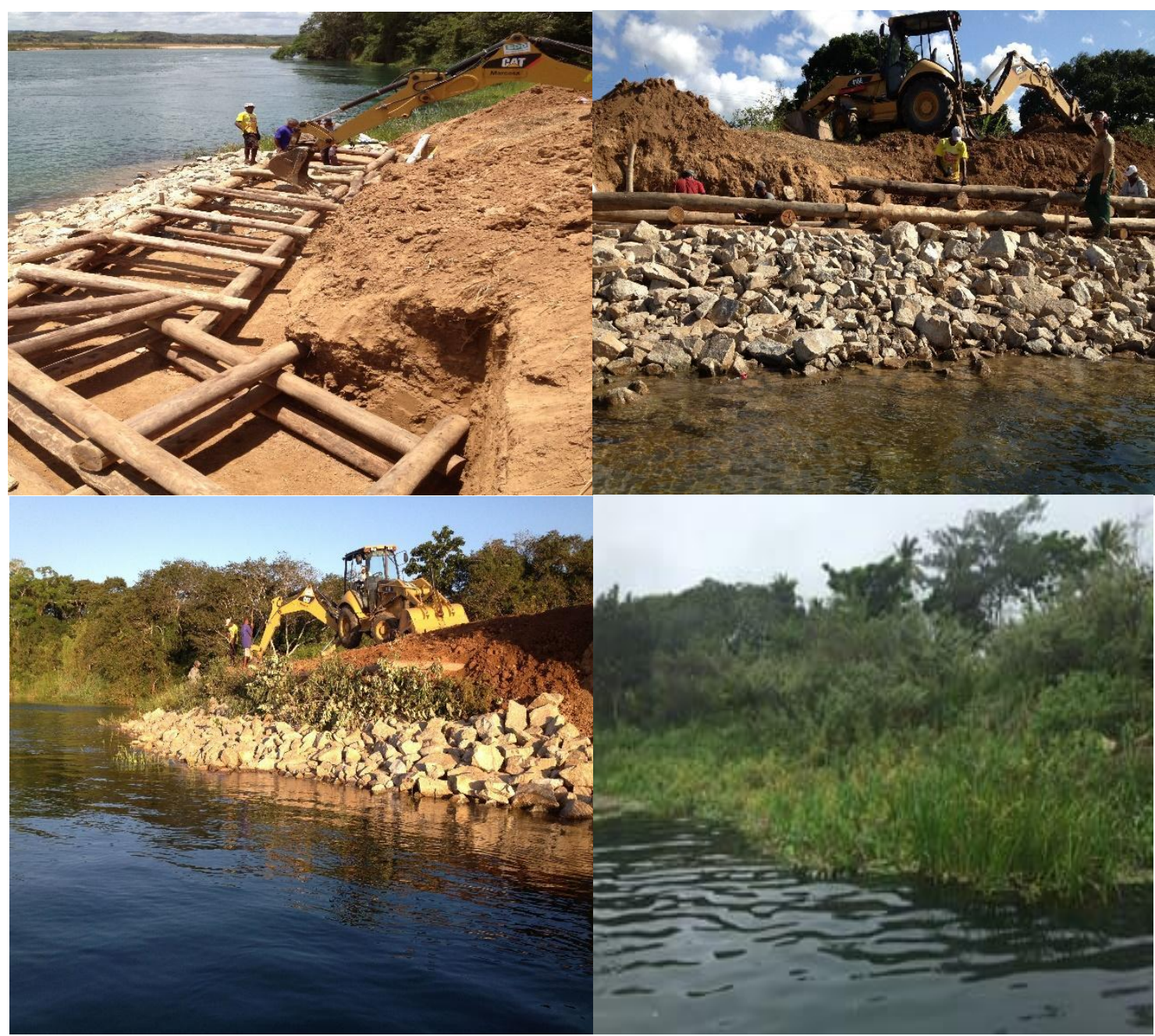

Figure 11. Lower São Francisco Riverbank recovery, Northeastern Brazil, through soil bioengineering techniques called Crib-wall, from 2013 to 2018.

\section{CONCLUSIONS}

Soil bioengineering appears to be a very effective method for controlling bank erosion. The strengthening of river banks, depending on the technique, does not require very complex structural calculations and can be implemented with available raw materials in the region used to manufacture geotextiles with local fibres from Coccus nucifera L, Agave sisalana Perr, Syagrus coronata (Mart.) Becc., Typha latifolia, Linn.,and Juncus spp Vahl, etc.. Considering complex scenarios, a variety of studies is demanded mostly related to agronomy engineering, forest engineering, biology, pedology, geomorphology, geology and geotechnology. In environmentally sensitive locations, where preservation of scenery or wildlife habitat may be critical, soil bioengineering can offer more environmentally compatible solutions. Perhaps even more important for sensitive or remote sites, these measures require no long-term maintenance, and thereby minimize disturbances.

Soil bioengineering is not suitable for all situations and/or enviroments. When slopes are very steep or very high, and/or consist of low-cohesion soils, this technique may not be feasible.

The efficiency of the techniques used to control erosion may vary depending on the slopes, as well as on the natural dynamics of rivers. The adoption of these measures decreases erosion rates, reflecting in the sedimentological dynamics, and in the recovery of the vegetation cover, providing an environment for the development of flora and shelter for aquatic fauna, and the protection of banks and slopes as well. 
Permanent monitoring is needed in order to adjust the systems as necessary, considering we are dealing with possible changes mostly related to dynamic environmental issues involving hydrology, geomorphology, weather and others that affect species behavior.

\section{REFERENCES}

ARAÚJO-FILHO, R. N.; HOLANDA, F. S. R.; ANDRADE, K. R. Implementation of soil bioengineering techniques for erosion control of the Lower São Francisco river. Scientia Plena, v. 9, n. 7(a), 2013.

ARAUJO-FILHO, R. N.; HOLANDA, F. S. R.; PEDROTTI, A.; SANTOS, T. O.; LINO, J. B.; ROCHA, I. P. Influência dos atributos físico-mecânicos do solo na estabilidade do talude do rio São Francisco. Scientia Agraria, v. 18, n. 4, p. 107-113, 2017.

BANDEIRA, A. A.; HOLANDA, F. S. R.; CASADO, A. P. B.; ARAÚJO FILHO, R. N. DE. Influence of the flow and reflux of the aquifer on the evolution of the erosive process in the margin of the São Francisco river. Magistra, v. 24, n. 2, 2012.

BECK, W.; ISENHART, T.; MOORE, P.; SCHILLING, K.; SCHULTZ, R.; TOMER, M. Streambank alluvial unit contributions to suspended sediment and total phosphorus loads, Walnut Creek, Iowa, USA. Water, v. 10, n. 2, p. 111, 2018. https://doi.org/10.3390/w10020111

BIRNBAUM, C.; MORALD, T. K.; TIBBETT, M.; BENNETT, R. G.; STANDISH, R. J. Effect of plant root symbionts on performance of native woody species in competition with an invasive grass in multispecies microcosms. Ecology and Evolution, v. 8, n. 17, p. 8652-8664, 2018. https://doi.org/10.1002/ece3.4397

BLÁHOVÁ, K.; ŠEVELOVÁ, L.; PILAŘOVÁ, P. Influence of water content on the shear strength parameters of clayey soil in relation to stability analysis of a hillside in brno region. Acta Universitatis Agriculturae et Silviculturae Mendelianae Brunensis, v. 61, n. 6, p. 1583-1588, 2013. http://dx.doi.org/10.11118/actaun201361061583

BORDOLOI, K.; NIKAM, B. R.; SRIVASTAV, S. K.; SAHARIAH, D. Assessment of riverbank erosion and erosion probability using geospatial approach: a case study of the Subansiri River, Assam, India. Applied Geomatics, v. 12, n. 3, p. 265-280, 2020. https://doi.org/10.1007/s12518-019-00296-1

BRAIDA, J. A.; REICHERT, J. M.; REINERT, D. J.; SOARES, J. M. D. Cohesion and angle of internal friction associated with soil organic carbon and water content in Hapludult. Ciência Rural, v. 37, n. 6, p. 1646-1653, 2007. https://doi.org/10.1590/S010384782007000600022

CAPUTO, H. P. Mecânica dos solos e suas aplicações: fundamentos. 6. ed. Rio de Janeiro: LTC, 1988.

CAVAIllÉ, P.; DOMMANGET, F.; DAUMERGUE, N.; LOUCOUGARAY, G.; SPIEGELBERGER, T.; TABACCHI, E. et al. Biodiversity assessment following a naturality gradient of riverbank protection structures in French prealps rivers. Ecological Engineering, v. 53, p. 23-30, 2013. https://doi.org/10.1016/j.ecoleng.2012.12.105

CHILIMA, J. S.; GUNN, J. A. E.; NOBLE, B. F.; PATRICK, R. J. Institutional considerations 
in watershed cumulative effects assessment and management. Impact Assessment and

Project Appraisal, v. 31, n. $1, \quad$ p. 74-84, 2013. https://doi.org/10.1080/14615517.2012.760227

CHONG, C. W.; CHU, L. M. Growth of vetiver grass for cut slope landscaping: effects of container size and watering rate. Urban Forestry \& Urban Greening, v. 6, n. 3, p. 135141, 2007. https://doi.org/10.1016/j.ufug.2007.07.002

DAI, Z.; LIU, J. T. Impacts of large dams on downstream fluvial sedimentation: an example of the Three Gorges Dam (TGD) on the Changjiang (Yangtze River). Journal of Hydrology, v. 480, p. 10-18, 2013. https://doi.org/10.1016/j.jhydrol.2012.12.003

DE BAETS, S.; POESEN, J.; REUBENS, B.; WEMANS, K.; BAERDEMAEKER, J. DE; MUYS, B. Root tensile strength and root distribution of typical Mediterranean plant species and their contribution to soil shear strength. Plant and soil, v. 305, n. 1-2, p. $207-$ 226, 2008. https://doi.org/10.1007/s11104-008-9553-0

DURLO, M. A. Bioengenharia: manejo biotécnico de cursos de água. Santa Maria: O autor, 2005.

FOX, G. A.; FELICE, R. G. Bank undercutting and tension failure by groundwater seepage: Predicting failure mechanisms. Earth Surface Processes and Landforms, v. 39, n. 6, p. 758-765, 2014. https://doi.org/10.1002/esp.3481

HILLER, P. H.; ABERLE, J.; LIA, L. Displacements as failure origin of placed riprap on steep slopes. Journal of Hydraulic Research, v. 56, n. 2, p. 141-155, 2018. https://doi.org/10.1080/00221686.2017.1323806

HOLANDA, F. S. R.; ARAÚJO FILHO, R. N.; LIMA, J. C. B.; ROCHA, I. P. Comparison of different containers in the production of seedlings of vetiver grass for erosion control. Revista Brasileira de Ciências Agrárias, v. 7, n. 3, p. 440-445, 2012a. https://dx.doi.org/10.5039/agraria.v7i3a1717

HOLANDA, F. S. R.; BANDEIRA, A. A.; ROCHA, I. P.; ARAÚJO FILHO, R. N.; RIBEIRO, L. F.; ENNES, M. A. Controle da erosão em margens de curso d'água das soluções empíricas as técnicas de bioengenharia de solos. R. Ra'E Ga, n. 17, p. 93-101, 2009a.

HOLANDA, F. S. R.; BANDEIRA, A. Á.; ROCHA, I. P. DA; ARAÚJO FILHO, R. N. DE; RIBEIRO, L. F.; ENNES, M. A. Controle da erosão em margens de cursos d'água: das soluções empíricas à técnica da bioengenharia de solos. Raega - O Espaço Geográfico em Análise, v. 17, n. 1, p. 93-101, 2009b. http://dx.doi.org/10.5380/raega.v17i0.12404

HOLANDA, F. S. R.; GOMES, L. G. N.; ROCHA, I. P. DA; SANTOS, T. T.; ARAÚJO FILHO, R. N. DE; VIEIRA, T. R. S. et al. Crescimento inicial de espécies florestais na recomposição da mata ciliar em taludes submetidos à técnica da bioengenharia de solos.

Ciencia Florestal, v. 20, n. 1, p. 157-167, 2010. https://doi.org/10.5902/198050981770

HOLANDA, F. S. R.; ISMERIM, S. S.; ROCHA, I. P. DA; JESUS, A. S. DE; ARAÚJO FILHO, R. N. DE; MELLO JÚNIOR, A. V. DE. Environmental perception of the São Francisco riverine population in regards to flood impact. Journal of Human Ecology, v. 28, n. 1, p. 37-46, 2009c. https://doi.org/10.1080/09709274.2009.11906216

HOLANDA, F. S. R.; LINO, J. B.; SANTOS, M. H.; GARCEZ, T. B.; ARAÚJO FILHO, R. 
N. Biotechnical potential of Paspalum submitted to simple superphosphate doses and moisture content. Scientia Agraria, v. 18, n. 4, p. 43-49, 2017. http://dx.doi.org/10.5380/rsa.v18i4.54252

HOLANDA, F. S. R.; ROCHA, I. P. DA; OLIVEIRA, V. S. Estabilização de taludes marginais com técnicas de bioengenharia de solos no Baixo São Francisco. Revista Brasileira de engenharia agrícola e ambiental, v. 12, n. 6, p. 570-575, 2008. https://doi.org/10.1590/S1415-43662008000600002

HOLANDA, F. S. R.; SANTOS, C. M. DOS; CASADO, A. P. B.; BANDEIRA, A. A.; OLIVEIRA, V. S. DE; FONTES, L. C. DA S. et al. Análise Multitemporal e Caracterização dos Processos Erosivos no Baixo São Francisco Sergipano. Revista Brasileira de Geomorfologia, v. 8, n. 2, 2007. http://dx.doi.org/10.20502/rbg.v8i2.96

HOLANDA, F. S. R.; SANTOS, L. G. DA C.; SANTOS, C. M. DOS; CASADO, A. P. B.; PEDROTTI, A.; RIBEIRO, G. T. Riparian vegetation affected by bank erosion in the Lower São Francisco River, Northeastern Brazil. Revista Árvore, v. 29, n. 2, p. 327 336, 2005. https://doi.org/10.1590/S0100-67622005000200016

HOLANDA, F. S. R.; SANTOS, M. H. DOS; JESUS, J. B. DE; SANTOS, W. DE M.; SENA, E. DE O. A.; CHAGAS, T. X. et al. Sediment input from the São Francisco Riverbank under low discharge period. investigaciones Geográficas, v. 103, 2021a. https://dx.doi.org/10.14350/rig.60244

HOLANDA, F. S. R.; VIEIRA, T. R. S.; ARAÚJO FILHO, R. N. DE; SANTOS, T. DE O.; ANDRADE, K. V. S. DE; CONCEIÇÃO, F. G. DA. Propagation through cutting techniques of species occurring in the Lower São Francisco River in Sergipe State with different concentrations of indolbutiric acid. Revista Árvore, v. 36, n. 1, p. 75-82, 2012 c. https://doi.org/10.1590/S0100-67622012000100009

HOLANDA, F. S. R.; WANDERLEY, L. DE L.; MENDONÇA, B. DE S.; SANTOS, L. D. V.; ROCHA, I. P. DA; PEDROTTI, A. Formação de ondas e os processos erosivos nas margens do lago da UHE Xingó. Revista Brasileira de Geografia Física, v. 13, n. 2, p. 887-902, 2020. https://doi.org/10.26848/rbgf.v13.2.p887-902

HOLANDA, F. S. R.; WANDERLEY, L. DE L.; SANTOS, L. D. V.; ROCHA, I. P. DA; OLIVEIRA, M. V. S.; PEDROTTI, A. Boat-generated waves and erosion on the shore of the Xingó power plant reservoir. Revista Goeciências, v. 40, n. 1, p. 337-385, 2021 b.

ISLAM, M. S.; SHAHIN, H. M. Reinforcing effect of vetiver (Vetiveria zizanioides) root in geotechnical structures - experiments and analyses. Geomechanics and Engineering, v. 5, n. 4, p. 313-329, 2013. http://dx.doi.org/10.12989/gae.2013.5.4.313

JAFARNEJAD, M.; FRANCA, M. J.; PFISTER, M.; SCHLEISS, A. J. Design of Riverbank Riprap Using Large, Individually Placed Blocks. Journal of Hydraulic Engineering, v. 145, n. 12, p. 04019042, 2019. https://doi.org/10.1061/(ASCE)HY.1943-7900.0001641

JANSSEN, P.; CAVAILlÉ, P.; BRAY, F.; EVETTE, A. Soil bioengineering techniques enhance riparian habitat quality and multi-taxonomic diversity in the foothills of the Alps and Jura Mountains. Ecological Engineering, v. 133, p. 1, 2019. https://doi.org/10.1016/j.ecoleng.2019.04.017

KOTOKY, P.; DUTTA, M. K. Mechanisms and Spatio-temporal Variations of Meandering and Erosion-Deposition Statistics of the Dhansiri River, Assam. In: RAMKUMAR, M. et al. (eds.). Environmental Management of River Basin Ecosystems. [S.1.] Springer, 2015. p. 253-282. 
LANDIM, M. F.; PROENÇA, C. E. B.; SALES, A. B.; MATOS, I. S. Floristic characterization of an Atlantic Rainforest remnant in Southern Sergipe: Crasto forest. Biota Neotropica, v. 15, n. 1, 2015. https://doi.org/10.1590/1676-06032014003613

LANGAT, P. K.; KUMAR, L.; KOECH, R. Monitoring river channel dynamics using remote sensing and GIS techniques. Geomorphology, v. 325, p. 92-102, 2019. https://doi.org/10.1016/j.geomorph.2018.10.007

LI, J.; XIA, J.; ZHOU, M.; DENG, S.; ZHANG, X. Variation in reach-scale thalweg-migration intensity in a braided reach of the lower Yellow River in 1986-2015. Earth Surface Processes and Landforms, v. 42, n. 13, p. 1952-1962, 2017. https://doi.org/10.1002/esp.4154

LIU, D.; VALYRAKIS, M.; WILLIAMS, R. Flow Hydrodynamics across Open Channel Flows with Riparian Zones: Implications for Riverbank Stability. Water, v. 9, n. 9, p. 720, 20 set. 2017. https://doi.org/10.3390/w9090720

MACHADO, L.; HOLANDA, F. S. R.; PEDROTTI, A.; FERREIRA, O. J. M.; ARAÚJO FILHO, R. N. DE; MOURA, M. M. Effect of Vetiver Roots on Soil Resistance to Penetration in a Fluvic Entisol in the São Francisco Riverbank. Revista Caatinga, v. 31, n. 4, p. 935-943, 2018. https://doi.org/10.1590/1983-21252018v31n416rc

MACHADO, L.; HOLANDA, F. S. R.; SILVA, V. S. DA; MARANDUBA, A. I. A.; LINO, J. B. Contribution of the root system of vetiver grass towards slope stabilization of the São Francisco River. Semina: Ciencias Agrarias, v. 36, n. 4, p. 2453-2463, 2015. http://dx.doi.org/10.5433/1679-0359.2015v36n4p2453

MCCORMACK, D. E.; WILDING, L. P. Soil properties influencing strength of Canfield and Geeburg soils. Soil Science Society of America Journal, v. 43, n. 1, p. 167-173, 1979. https://doi.org/10.2136/sssaj1979.03615995004300010032x

MICKOVSKI, S. B.; van BEEK, L. P. H. Root morphology and effects on soil reinforcement and slope stability of young vetiver (Vetiveria zizanioides) plants grown in semi-arid climate. Plant and Soil, v. 324, n. 1-2, p. 43-56, 2009. https://doi.org/10.1007/s11104009-0130-y

MORTON, J. B.; BENEDITO, V. A.; PANACCIONE, D. G.; JENKS, M. A. Potential for industrial application of microbes in symbioses that influence plant productivity and sustainability in agricultural, natural, or restored ecosystems. Industrial Biotechnology, v. 10, n. 5, p. 347-353, 2014. https://doi.org/10.1089/ind.2014.0014

MOURA, M. M.; FONTES, C. DOS S.; SANTOS, M. H. DOS; ARAUJO FILHO, R. N. DE; HOLANDA, F. S. R. Prediction of soil loss in the Lower São Francisco river in Sergipe $\begin{array}{llllllll}\text { state. Scientia Agraria, v. 18, n. 2, p. 126-135, } 2017 . & \text {. }\end{array}$ http://dx.doi.org/10.5380/rsa.v18i2.50143

MOURA, M. M.; SANTOS FONTES, C. DOS; SANTOS, M. H. DOS; ARAUJO FILHO, R. N. DE; HOLANDA, F. S. R. Estimativa de perda de solo no Baixo São Francisco sergipano. Scientia Agraria, v. 18, n. 2, p. 126-135, 2017. http://dx.doi.org/10.5380/rsa.v18i2.50143

PAL, K.; RAHMAN, A.; YUNUS, A. Analysis on River Bank Erosion-Accretion and Bar Dynamics Using Multi-Temporal Satellite Images. American Journal of Water Resources, v. 5, n. 4, p. 132-141, 2017. https://dx.doi.org/10.12691/ajwr-5-4-6 
PETRONE, A.; PRETI, F. Soil bioengineering for risk mitigation and environmental restoration in a humid tropical area. Hydrology and Earth System Sciences, v. 14, n. 2, p. 239, 2010. https://doi.org/10.5194/hess-14-239-2010

PETTS, G. E. Time-scales for ecological change in regulated rivers. In: CRAIG, J. F.; KEMPER, J. B. (eds). Regulated Streams. Boston: Springer, 1987. p. 257-266. https://doi.org/10.1007/978-1-4684-5392-8_17

RIBEIRO, L. F.; HOLANDA, F. S. R.; ARAÚJO FILHO, R. N. DE; ROCHA, I. P.; GOIS, S. S. Alterações de paisagens ribeirinhas: o caso do Rio Paramopama, estado de Sergipe. Floresta, v. 41, n. 2, 2011. http://dx.doi.org/10.5380/rf.v41i2.21870

RIBEIRO, M. C.; METZGER, J. P.; MARTENSEN, A. C.; PONZONI, F. J.; HIROTA, M. M. The Brazilian Atlantic Forest: How much is left, and how is the remaining forest distributed? Implications for conservation. Biological conservation, v. 142, n. 6, p. 1141-1153, 2009. https://doi.org/10.1016/j.biocon.2009.02.021

ROCHA, I. P. DA; HOLANDA, F. S. R.; ARAÚJO FILHO, R. N.; CASADO, A. P. B.; BANDEIRA, A. A. Meteorological and hydrological variables on occurrence of riverbank erosion along lower São Francisco river. Revista Brasileira de Engenharia Agrícola e Ambiental, v. 17, n. 2, p. 137-144, 2013. https://doi.org/10.1590/S141543662013000200004

ROCHA, I. P. DA; HOLANDA, F. S. R.; ROLIM, M. M.; LINO, J. B.; ARAÚJO FILHO, R. N. DE. Magnitude and Spatiotemporal Variation of the Erosion on the Slope of the Lower São Francisco River, Northeastern Brazil. Journal of Experimental Agriculture International, p. 1-11, 2018. https://doi.org/10.9734/JEAI/2018/41944

SCHIECHTL, H. M.; STERN, R. Ground bioengineering techniques for slope protection and erosion control. 1st. ed. Oxford UK: Blackwell Scientific, 1996.

SILVA, A. J. N. DA; CABEDA, M. S. V. Influência de diferentes sistemas de uso e manejo na coesão, resistência ao cisalhamento e óxidos de $\mathrm{Fe}$, Si e Al em solo de tabuleiro costeiro de Alagoas. Revista Brasileira de Ciência do Solo, v. 29, n. 3, p. 447-457, 2005. https://doi.org/10.1590/S0100-06832005000300015

STOKES, A.; ATGER, C.; BENGOUGH, A. G.; FOURCAUD, T.; SIDLE, R. C. Desirable plant root traits for protecting natural and engineered slopes against landslides. Plant and soil, v. 324, n. 1-2, p. 1-30, 2009. https://doi.org/10.1007/s11104-009-0159-y

SWEENEY, B. W.; CZAPKA, S. J. Riparian forest restoration: why each site needs an ecological prescription. Forest Ecology and Management, v. 192, n. 2, p. 361-373, 2004. https://doi.org/10.1016/j.foreco.2004.02.005

TESTONI, A. J.; BACKES, F. A. A. L. A importância da topografia na recuperação de áreas degradadas. Ágora : revista de divulgação científica, v. 16, n. 2, p. 52-62, 2009. https://doi.org/10.24302/agora.v16i2.25

THORNE, C. R. Field measurements of rates of bank erosion and bank material strength. In: FLORENCE SYMPOSIUM, 1981, Florence. Proceedings[...] Wallingford: IAHS, 1981.p. 10. 